\title{
Application of the Coastal Hazard Wheel to assess erosion on the Maltese coast
}

\author{
Stefan Micallef, Anton Micallef, Charles Galdies* \\ Institute of Earth Systems, University of Malta, Msida MSD 2080, Malta
}

\section{A R T I C L E I N F O}

\section{Article history:}

Received 14 February 2017

Received in revised form

31 May 2017

Accepted 16 June 2017

Available online 28 June 2017

\section{Keywords:}

Climate change

Coastal hazards

Coastal Hazard Wheel

Coastal erosion

Coastline assessment

Coastal erosion management

Malta

\begin{abstract}
A B S T R A C T
This study provides an assessment of erosion hazard on the Maltese coast via application of the Coastal Hazard Wheel, a tool that also facilitated analysis of a number of other inherent coastal hazards including ecosystem disruption, gradual inundation, salt water intrusion, and flooding. The $\mathrm{CHW}$ characterises the coastal environment by considering geological layout, wave exposure, tidal range, flora and fauna, sediment balance and storm climate. Application of the $\mathrm{CHW}$ identified coastal erosion to present a high to very high influence on the Maltese coastline, with $45.7 \%$ of the coast exhibiting a low level of erosion hazard, $12.1 \%$ a moderate level, $12.6 \%$ a high level and $18.4 \%$, a very high level of erosion hazard.

Application of the $\mathrm{CHW}$ suggested somewhat higher erosion hazard levels than prior studies using different methodologies; it also confirmed the ease of application of this climate change sensitive coastal hazard identification tool. Management considerations identified a wide range of options the applicability of which is highly dependent on specific coastal configuration and that characterisation of the latter is crucial to allow appropriate management.

The study generated management-useful maps describing coastal susceptibility to various hazards and hazard levels. It further provided a description of the entire Maltese coast in terms of ten different coastal configurations that infer management considerations of six coastal characteristics and five hazards. The study outputs are presented as a contribution to more effective management and decision-making by civil protection and planning agencies and as a key first step in the risk analysis process.
\end{abstract}

(c) 2017 Elsevier Ltd. All rights reserved.

\section{Introduction}

The study of climate change is a relatively recent topic that has rapidly gained attention in present day societies. Gradual changes in climatic features of the earth are relatively normal, but the fast rate of industrialization, together with scientific and technological advances have led to the disruption of such natural patterns. In fact, the anthropogenic influence on our atmosphere due to the emissions of $\mathrm{CO}_{2}$ and other greenhouse gasses has changed climatic patterns that we have been used to and has led to a phenomenon known as global warming (Hardy, 2003). The IPCC fifth assessment report has clearly shown that some of the main evidence of climate change is the increase of land and ocean temperatures in past decades, the alterations to hydrological patterns and also the modification of biological systems such as the migration of both

\footnotetext{
* Corresponding author.

E-mail addresses: stefan_micallef@hotmail.com (S. Micallef), anton.micallef@ um.edu.mt (A. Micallef), charles.galdies@um.edu.mt (C. Galdies).
}

terrestrial and marine species in order to adapt to the ever changing climate. Last but not least, research has also shown that humans are already being affected by climate change and in the longer-term, such impacts are very likely to get worse leading to modification of living standards (IPCC, 2014). Apart from higher global temperatures, we have been experiencing an increase in catastrophic events such as hurricanes, intense rainfalls and an accelerated melting of polar ice sheets, which in turn lead to sea level rise (USGCRP, 2014).

The influence of climate change is particularly relevant to coastal zones and associated coastal communities (Nicholls et al., 2007). According to Creel (2012), about half of the global population live within $200 \mathrm{~km}$ of the coast and these figures are likely to double by 2025 . Furthermore, the relatively small size and low topographic coastlines of small island states such as Malta, together with limited financial and technical opportunities and adaptive capacities, makes these countries very susceptible to extreme weather events, flooding and sea level rise (Mimura et al., 2007; Galdies, 2015). The United Nations Framework Convention on 
Climate Change (UNFCCC) also identifies small island developing states (SIDS) as the most vulnerable to the extreme weather events arising from climate change. As a result, consideration and implementation of adaptive measures on a national scale take on a high priority, in order to ensure protection of the limited resources present on such islands and at the same time ensure that the public is able to adapt to different conditions brought about by climate change (UNFCCC, 2005; Baldacchino and Galdies, 2015).

Located centrally within the Mediterranean Sea, the Maltese archipelago has a total area of about $316 \mathrm{~km}^{2}$, of which approximately $252.8 \mathrm{~km}^{2}$ are coastal areas (Planning Authority, 2002). The three main islands of Malta, Gozo and Comino share a total coastal length of about $173 \mathrm{~km}$ (National Communication of Malta to the UNFCCC, 2014), $60 \%$ of which is quite inaccessible due to its relief and/or geological features. The other $40 \%$ is highly urbanized, especially in the Grand Harbour area on the north-east coast of Malta which houses the main concentration of the island's population (Policy Research Corporation, 2009). Circa 5\% of Malta is about $7.6 \mathrm{~m}$ above sea level and $1 \%$, about $1 \mathrm{~m}$ above sea level (Briguglio, 2000). It follows therefore, that Sea Level Rise (SLR) and coastal floods constitute an increased threat for this part of the Maltese coast.

Tectonic activity and faulting have tilted the island with a southwest (up to $253 \mathrm{~m}$ ) to north-east (less than $1 \mathrm{~m}$ above sea-level) slant (Magri, 2006). For such reasons, the different geomorphological characteristics present along the coast, have led to overdevelopment of most of the north-eastern low-lying coastal zones. Demand for urban and industrial development within the coastal zone is still on the increase due to the expansion of the tourism sector (MEPA, 2015) and the very high local population density of over 1200 persons per $\mathrm{km}^{2}$, making it is one of the highest in the world (NSO, 2015). As a consequence of its heavy utilisation, this low-lying coast of Malta has been classified as being relatively vulnerable to sea level rise and inundation (Policy Research Corporation, 2009). The main physical and socioeconomic indicators of the coastal zone of the Maltese islands have also been considered by several European Commission-led studies. According to these, under medium sea level rise conditions, the Maltese coastline subject to erosion is approximately $7 \mathrm{~km}$ (or $0.04 \%$ of the total).

In Malta, coastal protection policy is carried out at a national level by a number of government-led institutions. These include the Ministry for Sustainable Development, the Environment and Climate Change with the support by the Environment and Resources Authority (located within the same Ministry) in terms of environmental regulation under the Environment Protection Act, and by the Planning Authority (within the Planning Directorate, Office of the Prime Minister), in terms of land use and spatial planning (planning and regulation of land development) under the Development Planning Act. Actual maintenance and protection measures are normally undertaken and financed by individual entities carrying out development on the coast (MRRA, 2012).

While much work remains to be done with regards to the study of vulnerability to climate change-sensitive hazards and related adaptation measures, the Maltese government has to date formulated a 2009 National Mitigation Strategy and a 2012 National Climate Change Adaptation Strategy together with legislation targeting climate change-relevant emission reduction targets (MRRA, 2009, 2012; National Communication of Malta to the UNFCCC, 2014). While the National 2014 Communication of Malta to the UNFCCC lacked any detailed study on specific coastal area susceptibility to coastal hazards, it did highlight predicted sea level rise and increasing extreme weather events as a considerable threat to the island's highly populated coastal areas (in view of their potential impacts of inundation, coastal erosion and damage by storm surges, waves and high winds particularly on the Blue Clay geological formation when exposed at sea level). Furthermore, the Communication identified $1.11 \mathrm{~km}^{2}$ or $0.36 \%$ of the island's coastline as being susceptible to sea level rise, with beaches particularly prone to erosion. While coastal development, protected areas, ports, infrastructures and roads were highlighted as being particularly vulnerable to sea level rise, a wider range of largely coastal land-uses were considered as vulnerable to climate change in general. These included low-lying road networks in the North of the island, coastal land reclamation projects and man-modified (including urbanized) low-lying coastal areas. A possible indication of the priority that coastal erosion holds within Government agenda may be reflected by the use of European Union funds by the Maltese Government to address hazard-related issues such as the development of a national Storm Water Project against flash flooding and other smaller flood relief projects. Coastal protection against extreme storm events and sea level rise is largely limited to road/seafront protecting sea walls and harbour breakwater protection structures (Walker-Leigh, 2006). Between the 2000-2015 period, the local expenditure against flooding and coastal erosion was in the region of Euro 91 million. Of this, only Euro 1.7 million was allotted to coastal erosion in the form of beach nourishment projects (GHK, 2006). This is surprising given the inherent value of the Maltese coast. Given its small size, the entire island has been considered a coastal region and the GDP for this coastal zone has been calculated at Euro 6414 million (EEA, 2006; Doody et al., 2004; EUROSTAT, 2016).

The aim of this research was to carry out an assessment of erosion hazard levels along the Maltese coastline. The objectives included application to the Maltese coast of the Coastal Hazards Wheel (Appelquist and Halsnæs, 2015), a hazards assessment tool that assesses ecosystem disruption, gradual inundation, salt-water intrusion, erosion and flooding. This was achieved via the evaluation of:

- publicly available data;

- freely available, remotely sensed data;

- field data collected via ground-truthing exercises.

The significance of this study revolves around the absence of island-wide evaluation of coastal erosion hazard levels and the need to integrate such data into the longer-term process of risk assessment for the Maltese coast.

\section{Methodology}

Appelquist and Halsnæs (2015) have described the Coastal Hazard Wheel (CHW, 2.0 version), as a particularly versatile and standardised way to objectively assess the degree of erosion hazard of entire coastal stretches. The CHW has been recommended by the United Nations Environment Programme (UNEP) as a risk assessment tool to aid coastal managers, planners and policy makers assess how coastal areas are likely to be affected in relation to different hazard levels induced by climate change (Appelquist, 2013). This tool was mostly designed to enhance decision-making in developing states (Appelquist and Balstrøm, 2014), since it can be applied without the need of having extensive digital data availability (UNEP, 2012).

At its most basic, the CHW can be applied to assess hazard levels where data availability is limited to publicly available data and the use of freely available (e.g. Google Earth) remotely sensed data. This option facilitates a preliminary assessment of hazard types and location. While a more accurate (intermediate level) result may be obtained with the inclusion of ground-validated (in addition to remotely sensed data), a high accuracy and locally focused hazard 
assessment is possible with the use of detailed higher resolution in situ studies in support of the above two data categories. The method chosen for this study was carried out at the intermediate accuracy level by using in situ field observations and satellite imagery.

\subsection{Application of the Coastal Hazard Wheel}

The CHW (Fig. 1) is composed of successive layers representing a range of optional configurations for six coastal characteristics starting from the shoreline up to $200 \mathrm{~m}$ inland, followed by five rows describing different 'hazard levels' for five different climate change-sensitive coastal hazards. The centre of the wheel provides the starting point with eight possible geological layouts for the coastal environment being studied (sloping hard rock coast, sloping soft rock coast, flat hard rock coast, coral island, sedimentary plain, barrier island, delta/low estuary island, tidal inlet/sand spit/river mouth). Moving outwards, the next coastal characteristic considered is the level of wave exposure (expressed as exposed, moderately exposed or protected), followed by the tidal range (micro: $<2 \mathrm{~m}$, meso: $2-4 \mathrm{~m}$ and macro: $>4 \mathrm{~m}$ tidal), the flora and fauna band (intermittent marsh, intermittent mangrove, marsh/tidal flat, mangrove, marsh/mangrove, vegetated, not vegetated, coral or 'any'), the sediment balance band (balance/deficit, surplus, beach/ no beach and 'any'), and the storm climate recorded as presence or absence of tropical cyclones. With regard to the sediment balance coastal characteristics, the $\mathrm{CHW}$ provides five optional categories for the sediment balance characteristic (Appelquist, 2014); two options (beach/no-beach) are applicable to rock coasts while, a 'balance/deficit' category, groups coastal areas where the sediment balance is not clearly defined (i.e. coastal areas with a current stable sediment environment are included with those that have a deficit since the former are most likely to lose their balanced state due to climate change influences from sea level rise, increased storm frequency etc). A fourth 'Surplus' category refers to coasts where the sediment supply is sufficiently positive so as to minimise the likelihood of near future climate change influences. An 'Any' category is provided for a number of characteristics so as to limit the number of possible categories by referring to instances where a particular classification parameter has little importance to the overall classification (e.g. sediment grain size) or where it may be largely addressed by other parameters (e.g. in the case of local isostatic uplift/subsidence) (Appelquist and Halsnæs, 2015).

In this manner, the researcher moves from the centre of the CHW (addressing in turn, geological layout, exposure, tidal range, flora and fauna, sediment balance and storm climate) to the external edge where the inherent hazard levels (ranging from low, moderate, high and very high) are identified for ecosystem disruption, gradual inundation, saltwater intrusion, erosion and flooding.

Using the CHW, the researcher is thus able to identify the different hazard levels to which a particular coastal area can be potentially exposed to, by taking into consideration the interaction of different coastal hazards with the different coastal characteristics considered at each layer of the wheel. The outer edge of the CHW presents a range of 131 coded coastal environment configuration possibilities (coastal character plus hazard levels) for the eight core coastal geological layouts considered. The CHW layout was modified (Fig. 2) to increase its applicability to the local scenario by restricting its consideration to the core coastal geologic layouts (and subsequent coastal characteristics) applicable to the Maltese coast (Appelquist, personal communication, 2015).

In addition to assessing hazard types and levels, the CHW also proposes a matrix that provides hazard management options for each of the specific coastal type configurations possible (Appelquist and Halsnæs, 2015). This matrix considers the traditional though potentially sediment interrupting hard coastal protection measures, the less disruptive soft coastal protection measures and a suite of more recently developed 'accommodation' measures that provide the opportunity for inhabitation and use of hazard prone coastal areas by improving the user's ability to cope with increasingly changing and adverse conditions.

\subsection{Data collection, spatial vectorisation, categorisation and analysis}

Various data collection, analysis and display methods were used to provide the most accurate result possible. These included field observations and high-resolution satellite images (captured during April, 2013). During field observations, various coastal data such as vegetation cover (within $200 \mathrm{~m}$ from shoreline), sediment balance, coastal configuration and geological configuration were noted and recorded. The spatial extent of this study covered the entire coastal stretch of Malta (excluding Gozo and Comino). These observations were carried out between September and December 2014.

GIS tools were used to vectorise the coastline shape and relief in different areas based on detailed ground-truthing, using remote sensing images (UTM, Zone 33S) as the baseline information. In this manner, a thematic map categorising the coastline of Malta was produced according to the adapted CWH (Fig. 2), each with discrete colours and attribute information. A total of six layers were developed depicting all major components relevant to the Maltese coastline, these being (1) the geological layout of the Maltese coastline, (2) wave exposure in different parts of Malta, (3) the tidal range of the Maltese coast, (4) the vegetation cover within $200 \mathrm{~m}$ along the Maltese coastline, (5) the sediment balance across the island, and (6) the influence of storm climate on the Maltese coastline.

\section{Results and discussion}

Application of the CHW to the Maltese coast allowed characterisation of the Maltese coast (Table 1), identification of coastal erosion hazard levels for the island of Malta (Tables 2 and 3; Figs. 3 and 4) and ten different coded coastal types (Table 2) and their location along the Maltese coastline (Figs. 5 and 6). The total length in meters and percentage representation of the entire coastline was calculated for each of these outputs using the 'calculate geometry' option in the ESRI's ArcGIS software (version 10) attribute table.

\subsection{Characterisation of the Maltese coast using the CHW}

\subsubsection{Circular layer 1 - geological layout}

Characterisation of the Maltese coastline in relation to geological layout was conducted on the basis of published data and other publicly available information (Azzopardi, 1995; Magri, 2006; Magri et al., 2007, 2008; MRA, 2012; Pedley et al., 1976; Oil Exploration Directorate, 1993) and by means of successive field visits to coastal sites.

Of the 'geological layout' types presented by the standard CHW, those relevant to the Maltese coast, such as 'sloping soft rock coast', 'sloping hard rock coast' and 'flat hard rock coast' were selected for consideration (Fig. 2). The latter typology was identified in only a few locations ( $1.3 \mathrm{kms}$ over $0.7 \%$ of the assessed coastline - Table 1 ) in the form of shore platforms with a slope less than 3-4\% on the Salini coast on the north coast of Malta. Highly anthropogenised areas such as the Grand Harbour were generally complex to classify due to a common mix of generally narrow flat rock platforms backed by man-made seawalls. After consideration of how this type of coast is likely to interact with the coastal hazard being assessed 


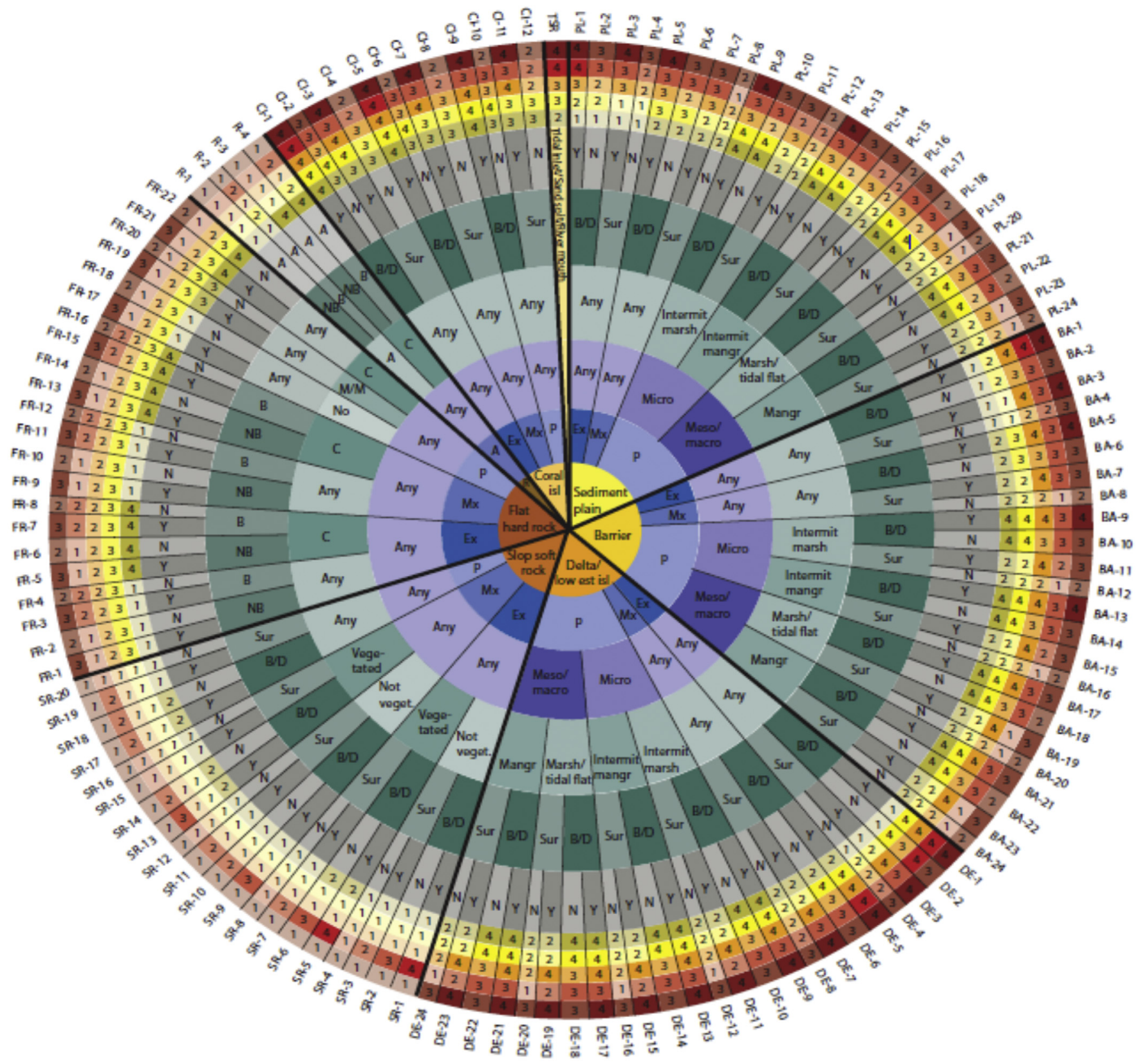

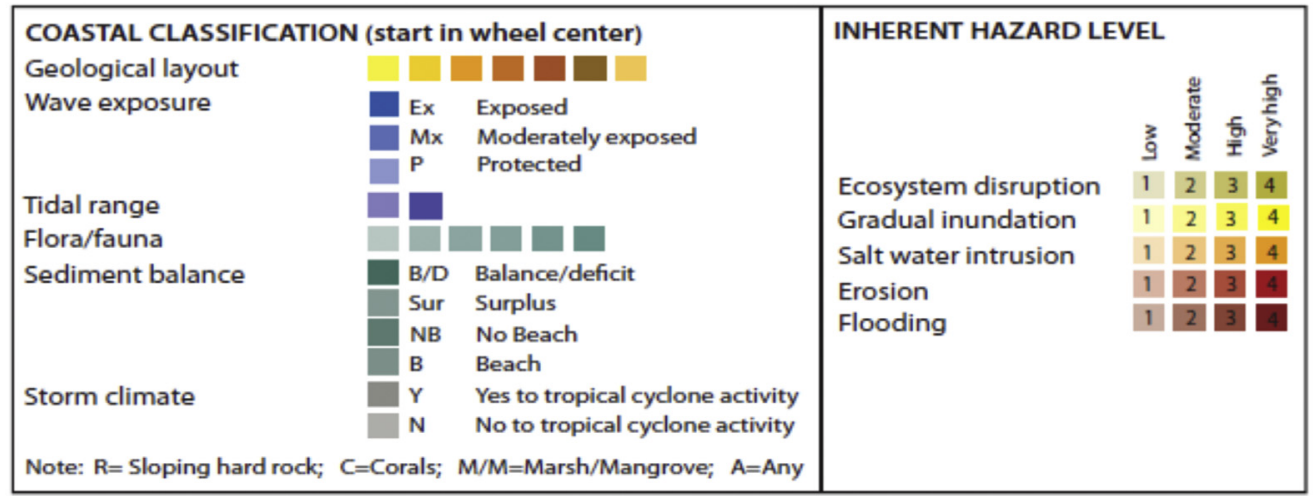

Fig. 1. The Coastal Hazard Wheel version 2.0 source: (Appelquist, 2014). 


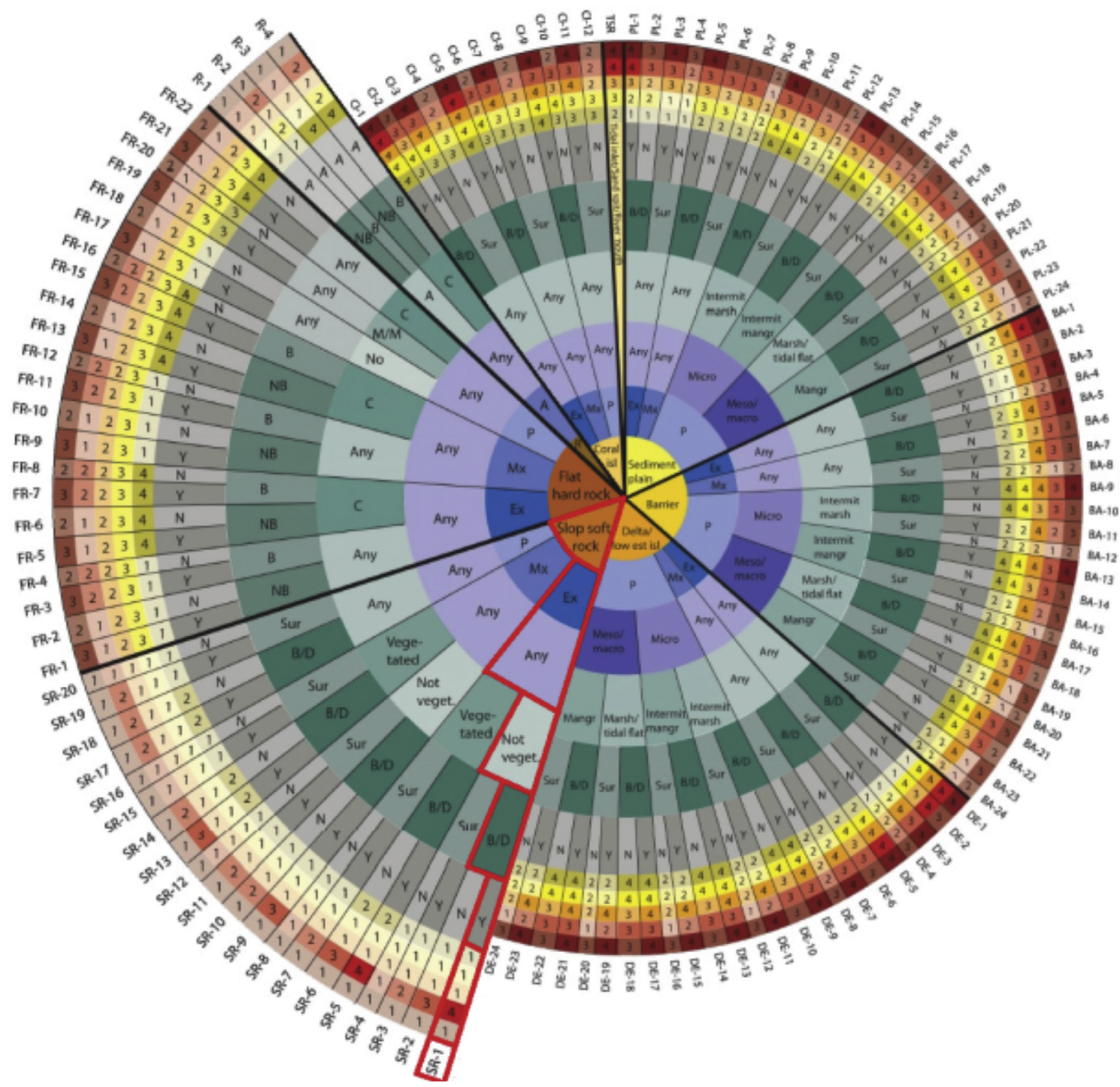

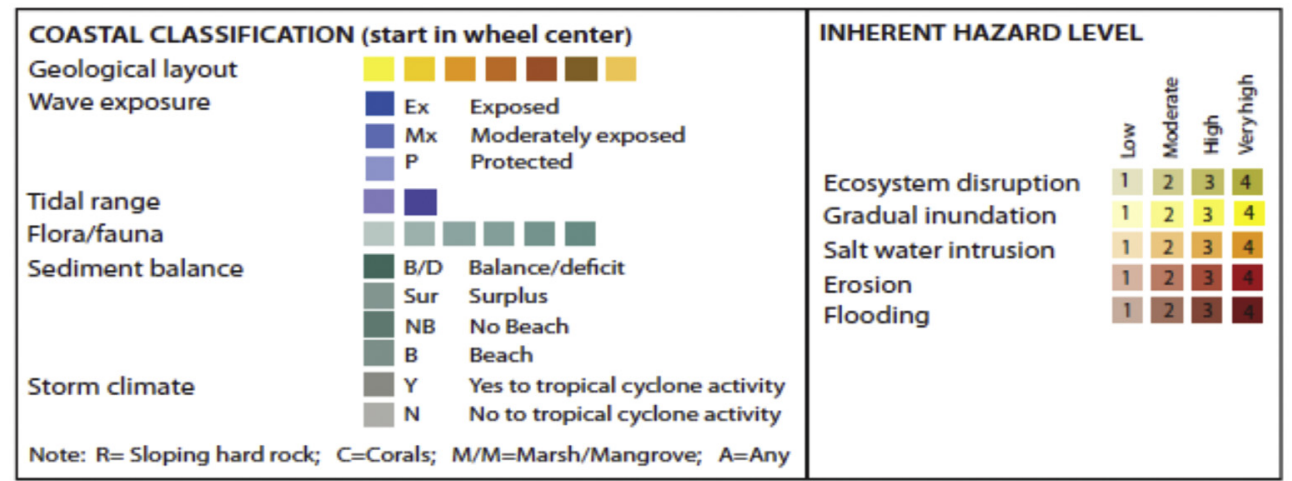

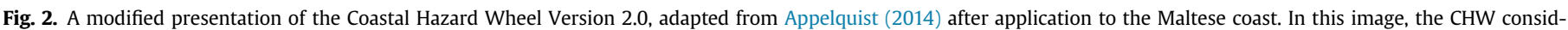

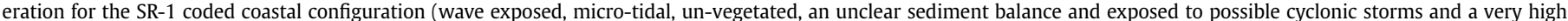
level of coastal erosion hazard) is earmarked. 
Table 1

Length and percentage distribution of coastal characteristics identified by application of the CHW to the Maltese coastline.

\begin{tabular}{lll}
\hline Coastal characteristic & Length $(\mathrm{km})$ & \% of coastline \\
\hline Sloping soft rock & 57.2 & 29 \\
Sloping hard rock & 116.7 & 59.3 \\
Flat hard rock & 1.3 & 3.0 \\
Protected (from wave action) & 19.1 & 0.7 \\
Moderately exposed & 36.4 & 9.7 \\
Exposed & 116.7 & 18.5 \\
Insignificant impact on coastal erosion by wave exposure & 175.2 & 39.8 \\
Insignificant impact on coastal erosion by micro-tide & 19 & 100 \\
Vegetated & 119.4 \\
Un-vegetated & 57.2 \\
Insignificant impact on coastal erosion by vegetation cover & 1.7 \\
Balance/Deficit & 115.5 \\
Beach & 0.8 \\
No beach & 58.5 \\
Insignificant impact on coastal erosion by sediment balance & 116.7 \\
Insignificant impact on coastal erosion by storm climate & 9.7 \\
\hline
\end{tabular}

Table 2

Coded coastal environment type properties. Hazards are described as 1 (low), 2 (moderate), 3 (high) and 4 (very high) levels.

\begin{tabular}{|c|c|c|c|c|c|c|c|c|c|c|c|c|c|}
\hline \multirow{2}{*}{$\begin{array}{l}\text { Coastal } \\
\text { environ }\end{array}$} & \multicolumn{6}{|c|}{ Coastal characteristics } & \multicolumn{5}{|l|}{ Hazard levels } & \multirow{2}{*}{$\begin{array}{l}\text { Lengt h } \\
(\mathrm{km})\end{array}$} & \multirow{2}{*}{$\begin{array}{l}\% \text { of } \\
\text { coastline }\end{array}$} \\
\hline & $\begin{array}{l}\text { Geological } \\
\text { composition }\end{array}$ & $\begin{array}{l}\text { Wave } \\
\text { exposure }\end{array}$ & $\begin{array}{l}\text { Tidal } \\
\text { range }\end{array}$ & $\begin{array}{l}\text { Flora \& } \\
\text { fauna }\end{array}$ & $\begin{array}{l}\text { Sediment } \\
\text { balance }\end{array}$ & $\begin{array}{l}\text { Storm } \\
\text { climate }\end{array}$ & $\begin{array}{l}\text { Eco- System } \\
\text { disruption }\end{array}$ & Inundation & $\begin{array}{l}\text { Salt water } \\
\text { intrusion }\end{array}$ & Erosion & Flooding & & \\
\hline SR-17 & $\begin{array}{l}\text { Sloping soft } \\
\text { rock }\end{array}$ & Protected & Any & Any & $\begin{array}{l}\text { Balance } \\
\text { /Deficit }\end{array}$ & Yes & 2 & 1 & 1 & 2 & 1 & 2.2 & 1.1 \\
\hline SR-13 & $\begin{array}{l}\text { Sloping soft } \\
\text { rock }\end{array}$ & $\begin{array}{l}\text { Moderatel y } \\
\text { exposed }\end{array}$ & Any & Vegetated & $\begin{array}{l}\text { Balance } \\
\text { /Deficit }\end{array}$ & Yes & 2 & 1 & 1 & 3 & 1 & 12.3 & 6.2 \\
\hline SR-9 & $\begin{array}{l}\text { Sloping soft } \\
\text { rock }\end{array}$ & $\begin{array}{l}\text { Moderatel y } \\
\text { exposed }\end{array}$ & Any & $\begin{array}{l}\text { Not } \\
\text { vegetated }\end{array}$ & $\begin{array}{l}\text { Balance } \\
\text { /Deficit }\end{array}$ & Yes & 1 & 1 & 1 & 3 & 1 & 6.6 & 3.4 \\
\hline SR-5 & $\begin{array}{l}\text { Sloping soft } \\
\text { rock }\end{array}$ & Exposed & Any & Vegetated & $\begin{array}{l}\text { Balance } \\
\text { /Deficit }\end{array}$ & Yes & 2 & 1 & 1 & 4 & 1 & 24.5 & 12.4 \\
\hline SR-1 & $\begin{array}{l}\text { Sloping soft } \\
\text { rock }\end{array}$ & Exposed & Any & $\begin{array}{l}\text { Not } \\
\text { vegetated }\end{array}$ & $\begin{array}{l}\text { Balance } \\
\text { /Deficit }\end{array}$ & Yes & 1 & 1 & 1 & 4 & 1 & 11.6 & 5.9 \\
\hline $\mathrm{R}-2$ & $\begin{array}{l}\text { Sloping hard } \\
\text { rock }\end{array}$ & Any & Any & Any & Beach & Any & 1 & 2 & 1 & 2 & 1 & 1.7 & 5.9 \\
\hline R-l & $\begin{array}{l}\text { Sloping hard } \\
\text { rock }\end{array}$ & Any & Any & Any & No beach & Any & 1 & 1 & 1 & 1 & 1 & 115 & 58.4 \\
\hline FR-17 & Flat hard rock & Protected & Any & $\begin{array}{l}\text { Not } \\
\text { vegetated }\end{array}$ & Any & Yes & 1 & 3 & 2 & 1 & 3 & 0.8 & 0.4 \\
\hline FR-9 & Flat hard rock & $\begin{array}{l}\text { Moderatel y } \\
\text { exposed }\end{array}$ & Any & Any & No beach & Yes & 1 & 3 & 2 & 1 & 3 & 0.2 & 0.1 \\
\hline FR-1 & Flat hard rock & Exposed & Any & Any & No beach & Yes & 1 & 3 & 2 & 1 & 2 & 0.3 & 0.2 \\
\hline
\end{tabular}

Table 3

Percentage distribution of hazard levels along the Maltese coastline.

\begin{tabular}{lllll}
\hline \multirow{2}{*}{ Hazard } & Low & Moderate & High & Very high \\
\cline { 2 - 5 } & \multicolumn{2}{l}{ Distribution $(\%)$} & & \\
\hline Ecosystem disruption & 59 & 29.8 & 0 & 0 \\
Gradual inundation & 87.4 & 0.9 & 0.5 & 0 \\
Saltwater intrusion & 88.3 & 0.5 & 0 & 0 \\
Erosion & 45.7 & 12.1 & 12.6 & 18.4 \\
Flooding & 88.3 & 0 & 0.5 & 0 \\
\hline
\end{tabular}

and after consultation with the developer of the CHW, this type of coast was, for the purpose of this study, classed as 'Sloping Hard Rock'; in all, this type of geological layout was identified over 59.3\% (116.7 kms) of the coastline while the sloping soft rock was less frequent, identified over $29 \%$ (57.2 kms) of the coast (Table 1$)$.

\subsubsection{Circular layer 2 - wave exposure}

According to the Significant Wave Height Report of the Maltese Islands (MMA, 2003), and related literature (Mangor, 2004; Prahalad et al., 2015), the Maltese coastline may be considered as 'exposed' to wave action on the basis of a wave height ranging between 1.5 and $4.0 \mathrm{~m}$. This is equivalent to the highest option out of three possible wave exposure levels presented by the CHW. In areas such as the largely encompassed Grand Harbour of Malta, exposure to wave action was judged as 'moderately exposed' or 'protected', depending on the protected nature of the area in question. In this sense, the inner parts of the Grand harbour, and the existing yacht marinas at Ta' Xbiex, Vittoriosa, and Msida were all classified as 'protected' (Fig. 3). The outer parts of the harbour areas were classified as 'moderately exposed'. Overall, $3.0 \mathrm{~km}(1.5 \%)$ of the assessed coast of Malta was identified as protected from wave action, $9.7 \mathrm{kms}$ (19.1\%). as moderately exposed and $36.4 \mathrm{kms}$ (18.5\%) as exposed (Table 1).

\subsubsection{Circular layer 3 - tidal range}

With a local tidal range of approximately $0.6 \mathrm{~m}$, the Maltese coast is generally considered as a micro-tidal environment. However, all coastal areas characterised in this study as 'exposed' or 'moderately exposed' to wave action, were attributed the 'Any' category for tidal range. This is based on the argument that the influence by tidal range decreases with an increase in wave exposure (Masselink and Hughes, 2003 as cited in Appelquist, 2013) and thus the tidal regime of such areas is unlikely to induce any 


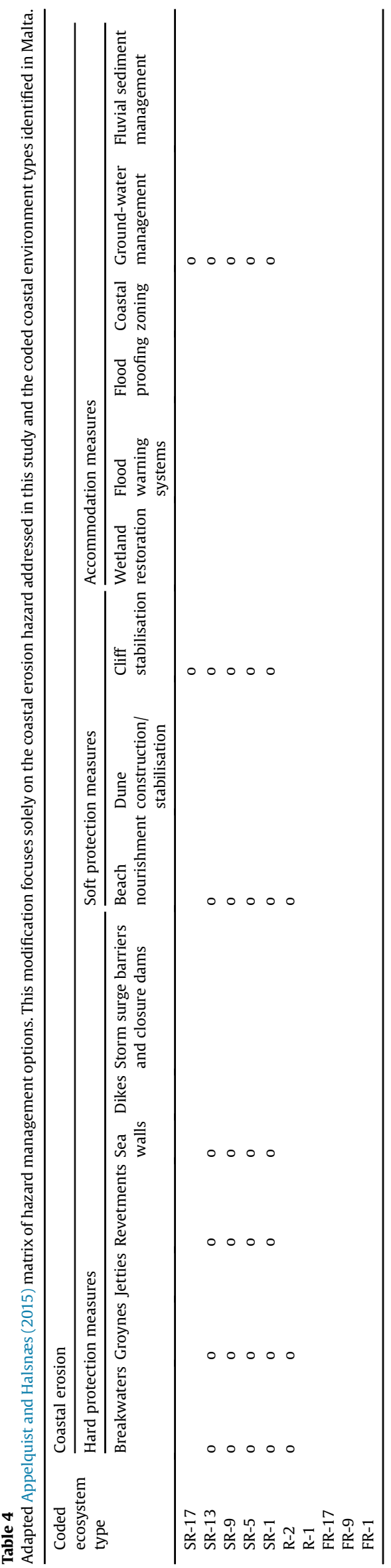

noticeable hazard. Similarly, coastal sections categorised as 'protected' from wave exposure, would normally be assigned the 'micro-tidal' category since these places are more likely to be influenced by tides, rather than by wave action (Gauci et al., 2005). However, as suggested by Appelquist (2013), 'protected' areas having sloping shore characteristics should also fall under the "Any" categorisation since the influence of tides in these areas will also not induce any noticeable hazards. As a consequence of the above arguments, the entire Maltese coastline was attributed the 'Any' tidal category (Table 1), since it is composed of 'exposed' and 'moderately exposed' (to wave action) areas together with some 'protected' category having a sloped relief.

\subsubsection{Circular layer 4 - flora and fauna}

Coastal vegetation can play a significant role in coastal stability by influencing the coastal sediment balance and erosion. Since local vegetation land-cover is highly susceptible to the influence by climate change (Galdies et al., 2016), it is an important factor to consider in the context of any study considering the hazard levels presented by erosion.

Of the vegetation cover options considered by the CHW, the 'Vegetated', 'Not vegetated' and 'Any' category options were identified as applicable to the local context. Along the Maltese coastline, these 3 categories refer to a variety of plants, shrubs and trees ranging from steppic communities in disturbed environments, to species from the maritime garrigue and also larger trees from the woodland habitat such as the Tamarix africana which characterize local coastal areas (MEPA, 2014; NTM, 2015). This study categorised an area as 'Vegetated' whenever the vegetation cover exceeded $25 \%$ (18.6\% of the assessed coast), while coasts with vegetation cover lower than $25 \%$ (9.7\%) was classified as 'Not vegetated' (Table 1). As with other coastal characteristics assessed by the CHW, vegetation cover was assessed from the shoreline to $200 \mathrm{~m}$ inland (Appelquist, 2014). The 'Any' category considered in this layer was attributed to those areas where vegetation was considered not to influence either coastal characteristics or potential hazards (Appelquist and Halsnæs, 2015). In this study, this classification category was attributed to a significant $60.7 \%$ or $119.4 \mathrm{kms}$ of the studied coastline (Table 1 ).

\subsubsection{Circular layer 5 - sediment balance}

Sediment availability in coastal areas plays an important role in shaping various coastal landforms. In the case of Malta, the majority of coastal sediments are generated from terrestrial (inland) sources, rock weathering and wave-generated erosion of the immediate shore (Micallef and Williams, 2009). Beaches in Malta are all pocket beaches and thus by definition, generally stable in terms of sediment balance. In this study, any shoreline type supporting a sand beach was attributed the 'beach' category $(0.9 \%)$ while sloping hard rock coasts devoid of sediment were allocated the 'no-beach' category ( $58.7 \%$ or $115.5 \mathrm{kms}$ of the studied coastline - see Table 1 ). Sloping soft rock coasts (including rock-armoured sloping soft rock headlands) were labelled with the Balance/Deficit category (29\%); this decision was based on the precautionary principle due to the inherent uncertainty on sediment status. None of the Maltese coast was identified as belonging to the 'Surplus' category while the 'Any' option was applied only in cases of flat rock shores where the sediment balance is unlikely to have any influence on the overall classification of this shore type.

\subsubsection{Circular layer 6 - storm climate}

The last coastal characteristic addressed by the CHW is the storm climate influencing the study area. While tropical storms are relatively scarce over the Mediterranean Sea, meso-scale cyclones are known to form. Known as Medicanes, these cyclonic episodes 


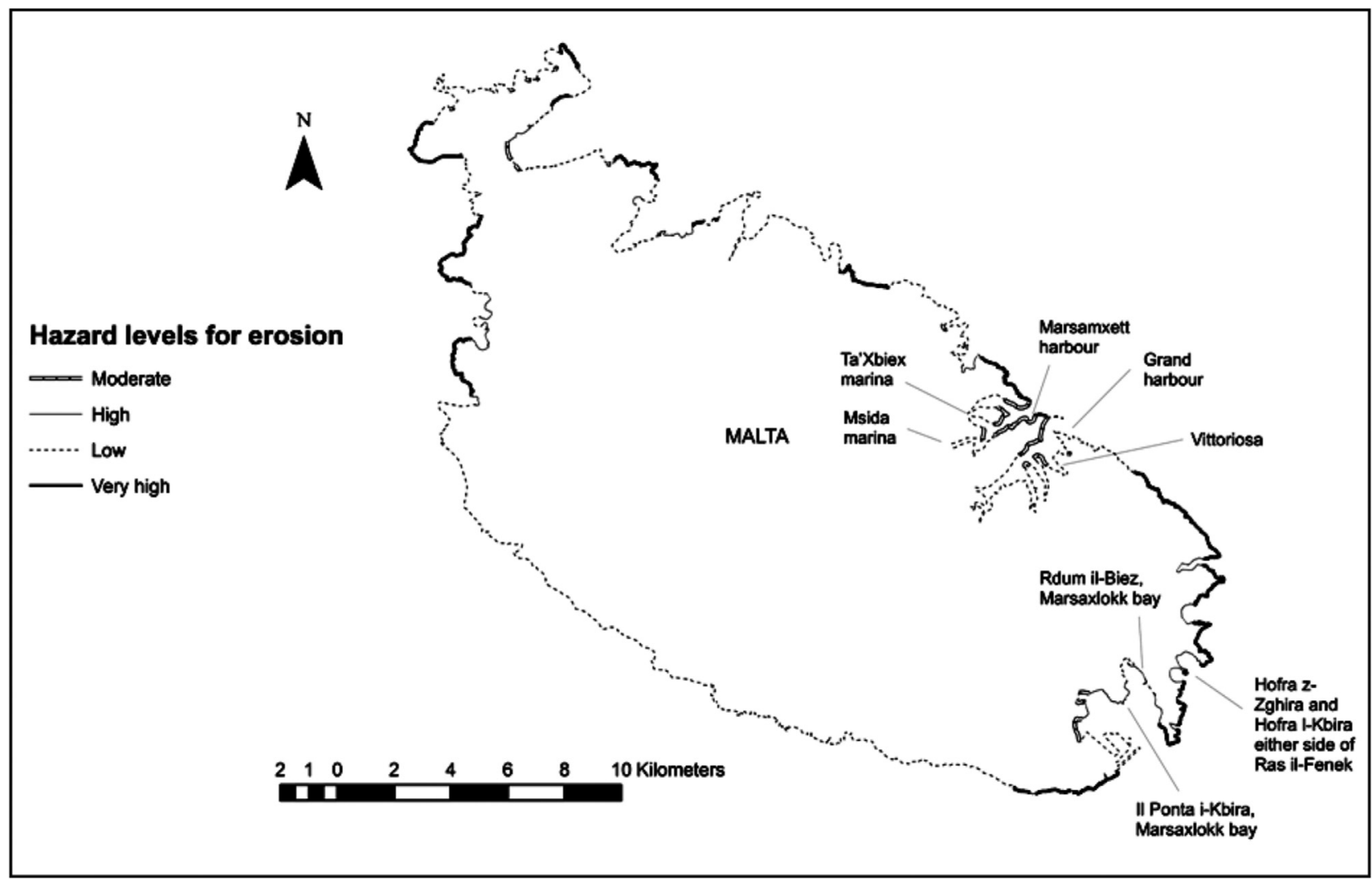

Fig. 3. Coastal erosion hazard levels for the Island of Malta.

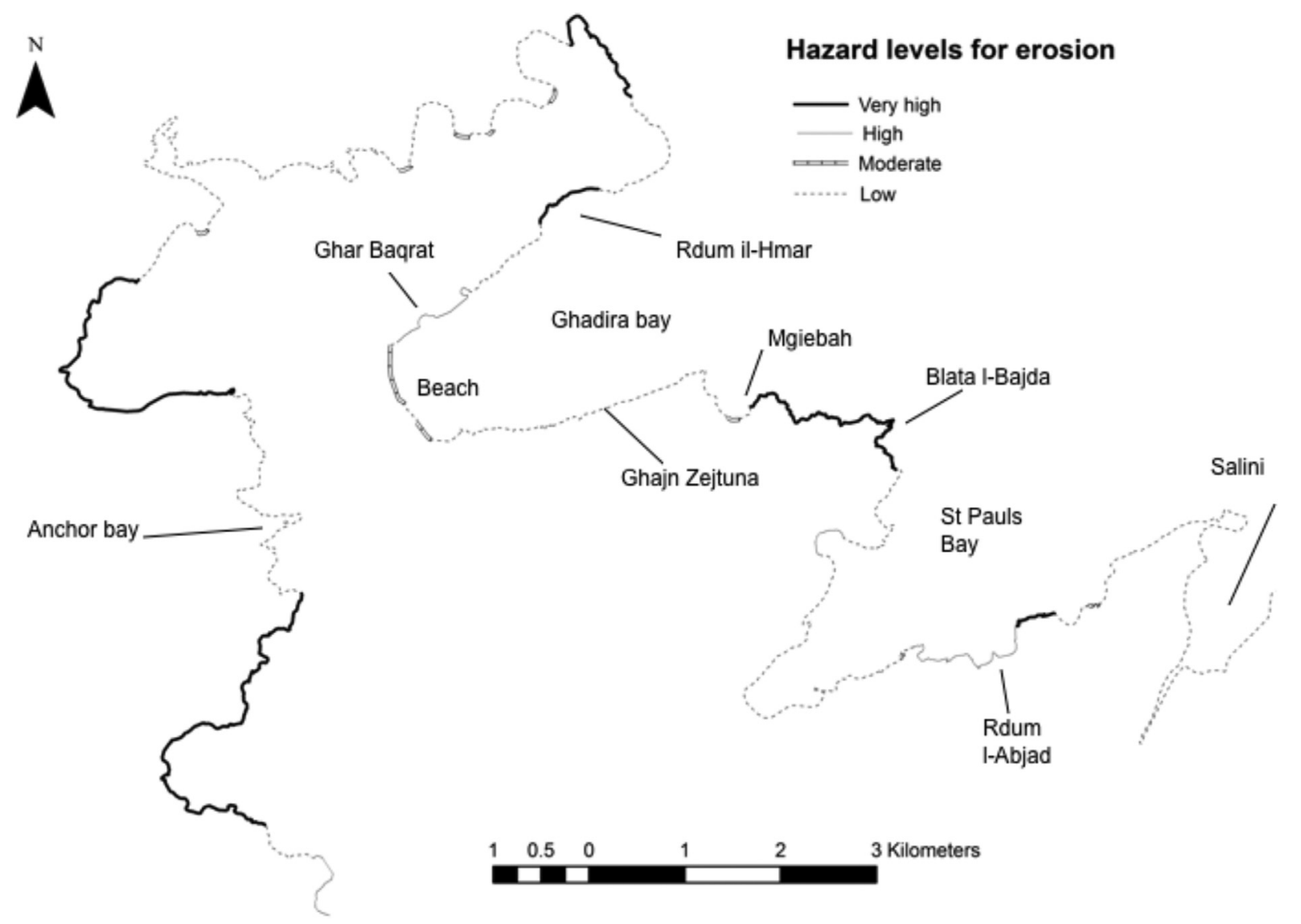

Fig. 4. Detail of the coastal erosion hazard level map for the west and north-east coast of Malta. 


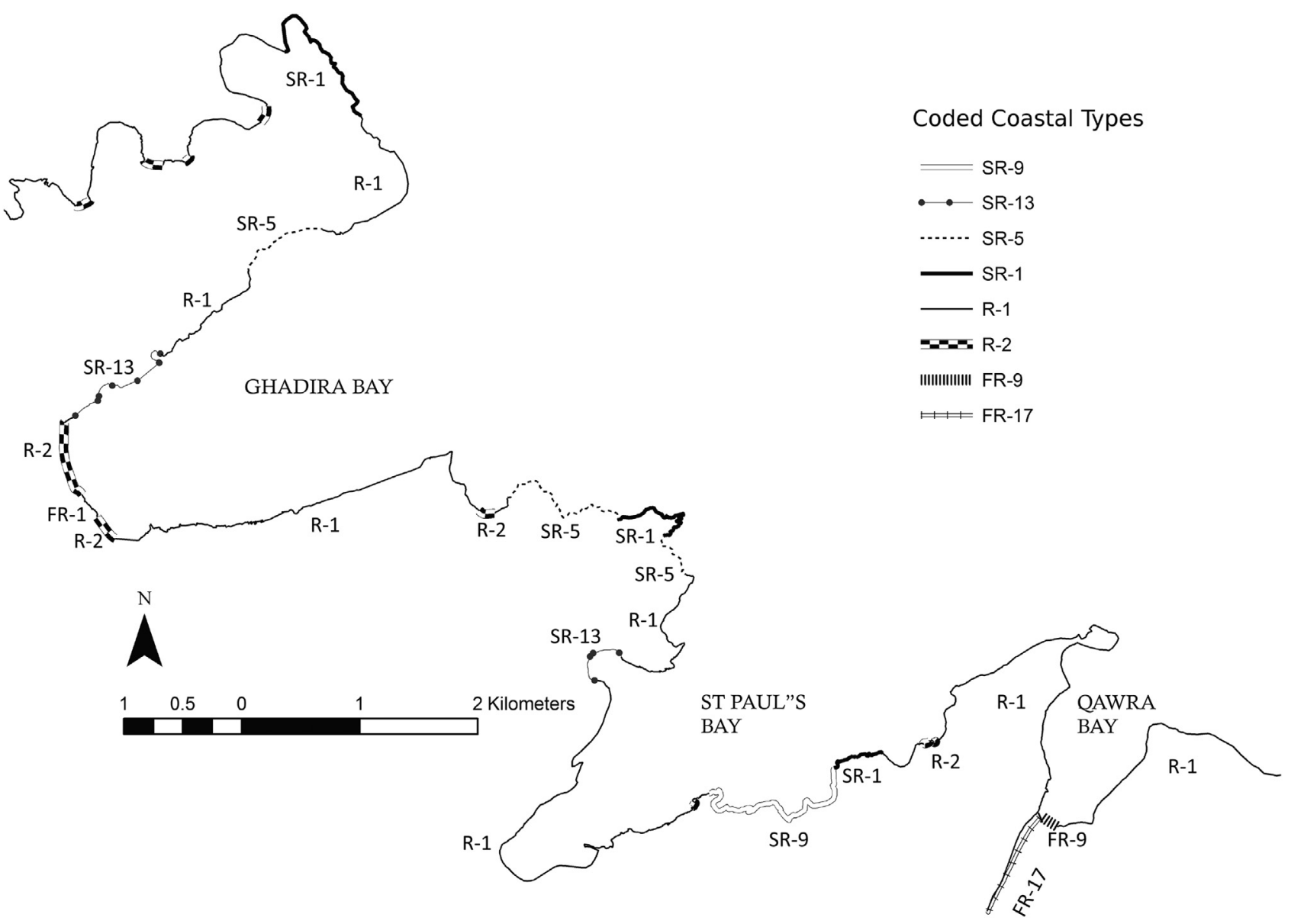

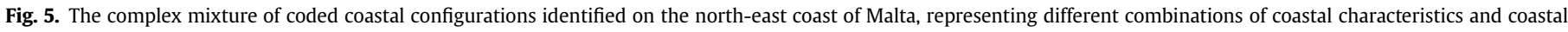
hazard levels (see Table 2 for code descriptions).

may reach maximum diameters of circa $300 \mathrm{~km}$ (Tous and Romero, 2013; Tous et al., 2013; Walsh et al., 2014). As a consequence and in view of the extremes in storm events experienced by the Maltese archipelago, severe storm climate influencing the Maltese coast was classed as representative of a tropical cyclone activity. While $29.7 \%(58.5 \mathrm{kms})$ of the studied coast was characterised as subject to storm climate influence, almost twice this amount (59.3\%/ $116.7 \mathrm{kms}$ ) was identified as experiencing insignificant influence on coastal erosion by storm climate (Table 1 ).

\subsection{Coastal erosion}

While the CHW assesses five inherent coastal hazards, this paper limits its main considerations to the coastal erosion hazard. Coastal erosion is highly site-specific due to its dependence on various aspects such as shore composition and wave exposure (Masselink et al., 2011). As a general rule, coastal areas having poorly consolidated sedimentary characteristics tend to be eroded faster than those areas having a hard composition. Moreover, lowlying coasts are also likely to be eroded faster, although this is very much dependent on the rock composition (IPCC, 2007).

In contrast to less alarming findings of earlier studies where only $0.04 \%(7 \mathrm{~km})$ of the coastal area in Malta was identified as strongly threatened by erosion (Policy Research Corporation, 2009) or where Malta was described as only moderately exposed to coastal erosion induced from climate change (Doody et al., 2004), this study identified that of all the coastal hazards evaluated, erosion was flagged as having the highest hazard value. The present methodology showed that slightly less than half of the Maltese coast $(45.7 \%)$ has a low level of erosion hazard, followed by a moderate level of $12.1 \%$, and a high and very high level of erosion hazard of $12.6 \%$ and $18.4 \%$ respectively (Figs. 3 and 4 ). This may be in part explained by the island's sedimentary geology and by the presence of sloping shorelines composed of a 'Blue Clay' limestone, particularly on the north-west coast of the island (Borg, 2004). In addition, human development of coastal areas primarily in the form of coast-hugging road networks are also likely to accelerate otherwise natural erosion process by interrupting sediment transfer to the coast and/or via the wave-reflecting action of road supporting seawalls. One should note that the CHW does not take into account anthropogenic coastal developments (such as roads and seawalls) and the prior assumption has been made on the basis of ancillary studies (Williams and Micallef, 2009).

Application of the CHW identified the eastern coast of Malta as exposed to all the erosion hazard level rating, ranging from 'low' to 'very high' (Fig. 3). As formerly discussed, erosion is highly dependent on the wave exposure of a particular coastal area and also on rock composition (Masselink et al., 2011). This methodology identified the highest erosion hazard levels on coastal areas characterised as 'exposed' to wave action, and composed of the locally 'softer' geological strata, such as Globigerina Limestone. On the other hand, coastal areas composed of the harder rock strata such as the Lower or Upper Coralline Limestone formations, were classed as having the lowest hazard levels, irrespective of their relative 


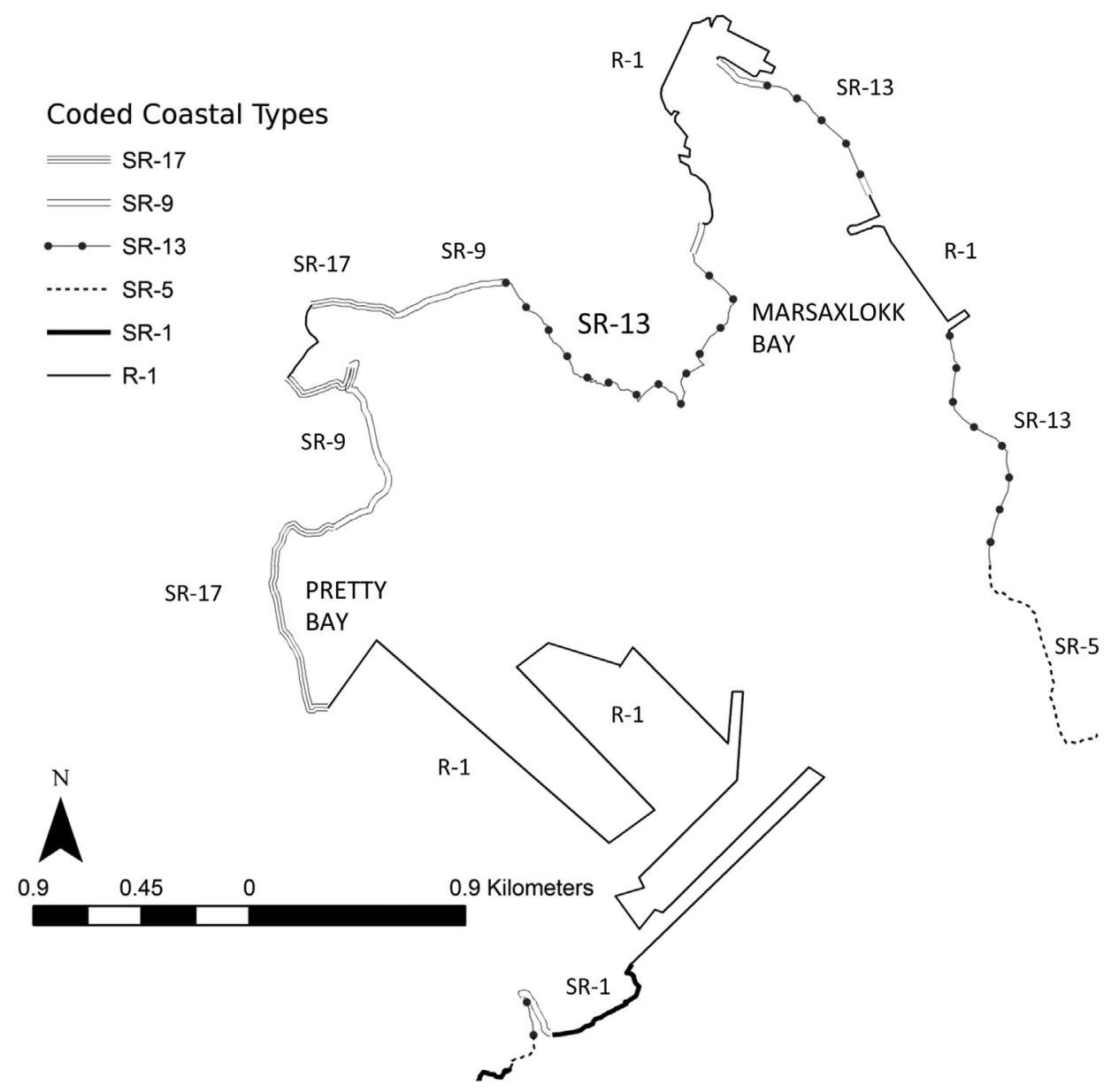

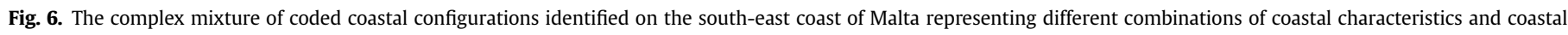
hazard levels (see Table 2 for code descriptions).

wave exposure. The only areas on this part of the coast that were classified under the 'moderate' erosion hazard levels were located in the Marsaxlokk and Birzebbugia area (Figs. 3 and 6).

While the southern coast of Malta was characterised as 'exposed' to wave action, it is mainly composed of a hard geological formation (Lower Coralline Limestone). Accordingly, based on the criteria set out by the IPCC (2007), this coastal area should not be very susceptible to erosion. This was verified by the application of the present modified CHW, which also resulted in a 'low' erosion hazard level classification for this coastal section (Fig. 3).

Exhibiting a variety of exposure levels, coastal configuration and geological characteristics, the western, north-western and northeastern coast of the Malta was, not surprisingly, allocated all four hazard levels for erosion (Figs. 3 and 4). The western coast, ranging from Fomm ir-Rih to Qammieh Point was mostly allocated 'High' and 'Very high' levels of erosion hazard (Figs. 3 and 4). This result reflects the largely 'soft' rock nature (e.g. of boulder-strewn Blue Clay slopes) of this coastline. On the same coastal section, while still characterised as 'exposed' to wave action, but strongly armoured with hard Upper Coralline Limestone boulders, the vertical cliffs either side of Anchor Bay (Fig. 4), was categorised as having a 'Low' level erosion hazard. While characterised as 'exposed' to wave action, the north-western coast (was classed by the CHW with a 'low' erosion hazard level due to its relatively hard geological composition (Upper Coralline Limestone).

The north-eastern coast of the island exhibited similarly varied coastal characteristics (Figs. 3 and 4), resulting in the classification of a mixture of 'very high' (e.g. Rdum il-Hmar coastal section of Ghadira Bay and Mgiebah to Blata l-Bajda coast separating Ghadira from St. Paul's Bay), 'high' (Ghar Baqrat section of Ghadira Bay and Rdum l-Abjad area within St. Paul's Bay), 'moderate' (Ghadira beach) and 'low' (Ghajn Zejtuna arm of Ghadira Bay and inner section of St Paul's Bay) erosion hazard levels. Of particular note for the north and north-eastern coast of the island (Fig. 3), is the erosion hazard level assessment for the largely encompassed Marsammxett and Grand Harbours. At these sites, exposure to wave action was judged as 'moderately exposed' or 'protected', depending on the depth of the area in question. In this sense, the inner parts of the Grand Harbour, especially the dock area in the Senglea-Marsa area and the existing yacht marinas at Ta' Xbiex, Vittoriosa, and Msida were all considered as 'protected' while the outer parts of the harbour areas were classified as 'moderately exposed' (Fig. 3). This, in connection with the 'Sloping Hard Rock' coastal classification of these areas, led to a 'low' costal erosion hazard label for the inner parts of the harbours and a 'moderate' level of coastal erosion hazard for the outer harbour areas (Fig. 3).

\subsection{Management considerations}

While a number of coastal erosion-specific management strategies are discussed below, it is recommended that such strategies should be considered within a sustainable development approach to coastal management i.e. one that necessarily considers both long-term and short-term measures and secondly, within an over- 
arching coastal hazard framework that necessarily also considers other types of coastal hazards. This is likely to prove not only more cost-effective but also more efficacious due to the often-interacting character of several coastal hazards such as the knock-on effect of sea level rise on coastal erosion, coastal inundation and flooding. Furthermore, a highly important aspect of the management of a hazard is the formulation of a strategy for its identification in the first instance and its monitoring in the long-term. From a broaderscoped perspective, hazard management would require a process that places a hazard within a risk management perception. To this end, the generation of hazard and vulnerability maps is an important step towards identification of risk and subsequently prioritizing mitigation efforts.

Different countries have addressed the world-wide problem of coastal erosion via different management strategies. In Europe for example, five policies have been adopted by the European Commission (Doody et al., 2004), namely the 'do nothing', 'hold the line', 'move seaward', 'managed re-alignment', and 'limited intervention' options. Given that the most appropriate coastal erosion management strategy is often determined by site specificity and prevailing conditions, it is not surprising that many countries have opted for a range of strategies. For example, both France and the United Kingdom have adopted the 'do nothing', 'hold the line' and 'managed re-alignment' strategies to combat erosion on different parts of their coasts. The least adopted management strategy is that of moving seaward. In this instance, where the current line of defense is extended seaward, the policy is necessarily limited to countries (such as Holland) that possess coastal areas with significant supplies of sediment allowing large-scale land reclamation. In this context, it can be argued that the choice of coastal erosion management strategy is not purely a strategic choice but one also influenced by the availability of financial and physical resources (such as the ready availability of sand).

Kay et al. (1994) have suggested a number of hazard management options and measures that include event protection (via hard and soft engineering approaches), damage prevention (via avoidance of certain types of development) and loss reduction measures (such as via relocation), the involvement of insurance measures to better distribute losses, a risk acceptance option via establishment of thresholds and finally, that of using of a mixed measures approach. An example of a combined hard and soft engineering approach, is that of an integrated boulder seawall/beach nourishment combination applied on the Goldcoast in Queensland, Australia (Lazarow et al., 2010). With an alignment parallel to the foreshore (as set by State Government), a seawall is buried at the back of the beach and used as a last line of defense. The seawall is designed to resist a one in 100 year cyclone event should such a storm erode the nourished beach. This management approach to coastal management has been accredited to stave off property and esplanade damage from major storms in the 1970s, 1990s and 2000s, which released their energy on the nourished beach, eroding it in parts but stopping short of further damage at the seawall (Cooper and Lemckert, 2012).

Coastal hazard management strategy may serve many aims. It should first and foremost, ensure mitigation of the negative effects of identified hazards so as to enable a sustainable land-use of that coastal environment. It should strive to raise public, managerial and policy maker awareness of any hazard-related risk issues and in so doing identify vulnerability to that hazard. Management strategy should also strive to improve the ability of vulnerable communities to better cope via improved adaptation measures. The long-term aim of hazard management strategy should be of risk reduction, not only to the public, but also to their property, their environment and their natural and cultural heritage (McInnes, 2009). Appelquist and Halsnæs (2015), have suggested a management matrix that considers the suitability of some of the more popular coastal erosion management options to the range of coded coastal environments and related hazard types described by the $\mathrm{CHW}$.

\subsubsection{Coastal erosion management strategy for Malta}

It appears that to date, the Maltese Islands have adopted a largely 'do nothing' and 'limited intervention' strategy towards management of coastal erosion. This may well be a consequence of the limited scientific work carried out, particularly at a national level, on coastal erosion (Farrugia, 2008) and on the broader concern of a national coastal risk management strategy. In place of a long-term national coastal erosion research programme, the majority of such studies tend to be one-off, dispersed and site-specific, emanating from university undergraduate and post-graduate studies, addressing topics such as beach and shore-platform erosion (Micallef, 2003; Micallef and Williams, 2009), aeolian sediment transport, cliff instability and rock spreading (Galea, D'Amico and Farrugia, 2014; Panzera, D'Amico, Lotteri, Galea and Lombardo, 2012). Knowledge on local coastal erosion may also have been hindered by past emphasis of concern being directed at the generating forces (e.g. strong winds and sea storms) and consequences (e.g. flooding and loss of soil) rather than on the primary hazard of coastal erosion itself. While only $2.5 \%$ of the Maltese coast is characterised by sandy beaches, this is a highly prized coastal resource due to increasing recreational demand from both overseas and local tourism (Williams and Micallef, 2009). While it appears that to date, Government efforts at mitigating erosion of sand beaches have been addressed via the development of beach nourishment projects, it may also be argued that this effort has been highly limited in scale and that its goal has only been reached indirectly, via the desire for increased tourism and recreational facilities rather than as a direct concern on coastal erosion.

In this context, the CHW is in this study, presented not only as a coastal erosion hazard management tool but more so, as an effective management strategy for the Maltese Islands, in the sense that it has been shown to be able to identify coastal areas requiring priority action and to offer potential mitigation options via a stepwise approach, identifying in turn:

- Coastal character (geological layout, wave exposure, tidal range, vegetation cover, sediment balance and storm climate (Table 1; Fig. 2).

- Coastal typology (representing different combinations of coastal characteristics) and reflecting different susceptibilities to coastal erosion (Table 2; Figs. 5 and 6).

- Location and length of coast exhibiting different coastal erosion hazard levels (low, moderate, high and very high) (Figs. 3 and 4).

- Coastal erosion mitigation/management options (Table 4).

Table 4 is a modified presentation of the original Appelquist and Halsnæs (2015) management matrix as it only considers coastal erosion and the coded coastal environment types identified in this Malta study. As may be seen, application of this matrix reflects that management intervention in the form of hard/soft engineering structures and/or accommodation measures may not always be applicable to all the coded coastal environment types identified on the Maltese coast. For example, while beach nourishment, groynes and breakwaters are suggested as applicable to R-2 type coast (sloping hard rock with beach as identified for example at Ghadira Bay - Tables 2 and 4; Fig. 5), none of the three main management options considered by the CHW are deemed applicable to the R-1, FR-17 (Fig. 5) and FR-1 type coasts. In part, this results because not all coastal types identified on the Maltese coast are subject to significant erosion hazard level that warrant costly management intervention and secondly because some of the management 
measures listed in the matrix (e.g. storm surge barriers and flood warning systems) are more relevant to flooding than to coastal erosion. Furthermore, in the case of sloping hard rock coasts without a beach and an 'Any' wave exposure categorisation (R-1) the influence of wave exposure is unlikely to have a significant influence on coastal erosion as these coasts are nature's answer to optimum diffusion of wave energy and thus rarely requiring management intervention. In the case of FR-17 type coast, its' protected status mitigates to a large degree the threat of coastal erosion. The FR-1 type coasts are the more complex to consider. Exposed to wave action and having no beach, the coastal erosion management measures called for this type of coast are dependent on a number of considerations:

- Shore platform width: Given a micro-tidal environment, a sufficiently-wide shore platform is likely to experience wave energy diffusion over its width and thus prior to impact on the potentially less resistant backshore. In this scenario, a 'do nothing' approach would be recommended. However, in the case of a narrow shore platform, where the backshore is more likely to experience a much higher wave energy impact, considerations of coastal erosion mitigation may be prioritised.

- Erosion resistant nature of the bedrock: While a shore platform feature is in itself, a reflection of an erosion-resistant nature, different bedrocks will exhibit different levels of resistance. Within the local (Malta) Globigerina Limestone subdivisions, Micallef and Williams (2009) have identified a sharp difference in the mean surface-lowering rate of the Middle and Lower Globigerina Limestone layers (9.16 and $0.74 \mathrm{~mm} / \mathrm{year}$ respectively); this gives rise to typically stepped platform formations where these are exposed at sea-level.

- Backshore form: The type of backshore formation will reflect different susceptibility to coastal erosion and it may be reasoned that in the case of a soft rock/poorly consolidated backshore, coastal erosion management is prioritised. This can take the form of interventions indicated for SR-9 and SR-13 type coasts (see Table 4) whose moderately exposed sloping soft rock nature largely replicates the conditions for an FR-1 type coast with a soft rock backshore. While such management works can normally take the form of cliff stabilisation works, other types of interventions are also possible (see Table 4).

\subsection{Limitation and sources of error of the Coastal Hazard Wheel Version 2.0}

Even though the CHW has been developed to cater for worldwide application, with particular emphasis for countries with developing economies, some of the default coastal categories offered by the CHW might not be well-suited to all coastal scenarios and users should consider those coastal characteristics most applicable to their area(s) of study (Appelquist, 2014). As a consequence, the direct application of the CHW might lead to some classification errors. Similarly, the CHW's limitation to assess the prevailing environment within a restricted zone $(200 \mathrm{~m}$ inland from shoreline), may in the consideration of geological and spatial characteristics, omit the inclusion of some minor differences along the coastline that may be nonetheless influential on some of the hazards assessed. Here, the level of field survey detail becomes paramount in order to reduce those errors arising from available imagery resolution and human error in the interpretation of available data. The CHW methodology is not intended to provide an extremely detailed assessment of hazards to specific coastal areas, but is instead developed to provide a more general assessment of the main hazards that will influence the general coastline (Appelquist, 2014). A case in point from this study that reflects the type of methodological error possible (in this study, legitimate due to the intermediate level of field investigation adopted) involved the assessment of the il-Ponta l-Kbira and Rdum il-Biez coast within Marsaxlokk bay and the neighbouring il Hofra il Kbira and il Hofra izZghira on the eastern coast of Malta (Fig. 3). These areas were initially identified as exhibiting high levels of erosion hazard due to their erosion prone Globigerina Limestone formation and characterisation as 'protected' from wave exposure. In reality, this turned out to be an erroneous result since detailed field and desk studies identified that Globigerina Limestone is in fact composed of three separate Members exhibiting different resistance to erosion. In the above-mentioned result for the Marsaxlokk coast, the Globigerina Limestone is represented by the Middle Globigerina Limestone Member that exhibits a particularly high susceptibility to erosion (Micallef and Williams, 2009). In this context therefore, this coastal area should have been classed as exposed to a 'very high' (rather than 'high') level of erosion hazard. This result reflected the importance of recognising the level of confidence that can be placed on the use of the CHW but sustained by the level of detail of field investigative work carried out in support of available public information and satellite data.

\section{Conclusions}

In characterising the Maltese coast, this study has shown that with the exception of protected harbour areas, the Maltese coastline has a high exposure to wave action. Tidal range was considered as not having any significant influence on the coastal hazards assessed while vegetation land-cover (within the immediate 200 m-wide coastal strip) was identified as variable with areas being largely categorised as having either more or less $25 \%$ vegetation cover. Apart from a limited number of generally small pocket beaches and a more significant section of toe-armoured, boulderstrewn coastal clay slopes (having an undetermined sediment balance), the majority of the coastline was identified as rocky. Severe storm climate influencing the Maltese coast was determined as one occasionally experiencing tropical cyclone strength activity.

Application of the $\mathrm{CHW}$ in this study identified that of all the coastal hazards evaluated, erosion was highlighted at the highest levels of threat to the Maltese coastline. Almost half of the coast (45.7\%) exhibited a low level of erosion hazard, $12.1 \%$ a moderate level, $12.6 \%$ a high level and $18.4 \%$ of the Maltese coast exhibiting a very high level of erosion hazard. Application of the CHW to the Maltese coast also identified nine different coded coastal types and their location along the Maltese coastline.

The study identified that the applicability of a range of coastal erosion management options, is highly dependent on the specific coastal configuration, the characterisation of which is crucial to allow the correct management approach. The choice of erosion management strategy however, is not purely a strategic one but it also influenced by the availability of financial and physical resources. In this context, the study recommended that management strategies should be considered within a sustainable development context and a wider-scoped coastal hazards framework.

Application of the CHW identified that different parts of the Maltese coastline are subject to different levels of different hazard types; varying key coastal characteristics may be seen to play a highly influential role in this determination. In this context, the CHW was seen as a highly versatile tool in facilitating production of highly informative hazard-related maps describing different coded coastal environments that represent the influence of different combinations of coastal characteristics on hazard levels. These present valuable data-sets that provide the necessary information for guiding coastal managers, civil protection authorities and related decision/policy makers in adopting appropriate coastal 
protection and mitigation measures to limit vulnerability of the Maltese coastline to such hazards.

The need for more extensive and long-term studies on coastal erosion at island-wide scale and within a risk management umbrella strategy, was identified; repeated application of the $\mathrm{CHW}$ tool accompanied by detailed field surveying may provide a strategy towards addressing this need. This would provide a more detailed assessment on coastal hazards for decision-making. In this context, the CHW may also be considered as a priority setting tool, identifying areas having a high level to natural hazards.

Additional parameters in the characterisation of coastal environments that may take on particular regional importance could be considered in future research. High levels of humidity for example, will influence weathering rates and in turn, susceptibility to erosion. Similarly, added consideration of the 'level of human intervention/presence' on a coastal environment may influence it's inherent hazard levels. For example, the construction of coastal protection structures such as seawalls will surely influence the currently considered 'geological layout' parameter. With Europe for example, this would be highly relevant given the already high proportion of concretized coast in this region and the provision of 'a largely artificialized coastline' parameter to the inner core of the CHW may be appropriate.

The CHW technique was considered as a very effective tool in the risk analysis process, where, given that vulnerability may be equated to the product of hazard intensity and susceptibility, the calculation/identification of coastal hazard intensity should also be seen as an important contribution to the subsequent assessment of vulnerability and eventually risk.

This research did not receive any specific grant from funding agencies in the public, commercial, or not-for-profit sectors.

\section{References}

Appelquist, L.R., 2013. Generic framework for meso-scale assessment of climate change hazards in coastal environments. J. Coast. Conserv. 17 (1), 59-74.

Appelquist, L.R., 2014. Decision-support for Climate Change Adaptation - Applications for Coastal Regions. Unpublished doctoral dissertation. Technical University of Denmark, Denmark.

Appelquist, L., Balstrøm, T., 2014. Application of the Coastal Hazard Wheel methodology for coastal multi-hazard assessment and management in the state of Djibouti. Clim. Risk Manag. 3, 79-95.

Appelquist, L., Halsnæs, K., 2015. The Coastal Hazard Wheel system for coasta multi-hazard assessment and management in a changing climate. J. Coast. Conserv. 19 (2), 157-179.

Azzopardi, A., 1995. A New Geography of the Maltese Islands. St Aloysius' College Malta.

Baldacchino, G., Galdies, C., 2015. Global environmental change: economic and labour market implications for small island territories. Xjenza Online 3, 81-85.

Borg, M., 2004. Xemxija-Ghajn Tuffieha (Malta), EUROSION Case Study. Shoreline Management Guide. http://www.eurosion.org.

Briguglio, L., 2000. Implications of accelerated sea-level rise (ASLR) for Malta. In: Proceeding of SURVAS Expert Workshop on European Vulnerability and Adaptation to Impacts of Accelerated Sea-level Rise (ASLR), Hamburg, Germany, 19th-21st June 2000.

Cooper, J.A.G., Lemckert, C., 2012. Extreme sea-level rise and adaptation options for coastal resort cities: a qualitative assessment from the Gold Coast, Australia. Ocean Coast. Manag. 64, 1-14.

Creel, L., 2012. Ripple Effects: Population and Coastal Regions. Population Reference Bureau, Washington, DC, USA. Retrieved February 6, 2015. http://www.prb.org Publications/Reports/2003/RippleEffectsPopulationandCoastalRegions.aspx.

Doody, P., Ferreria, M., Lombardo, S., Lucius, I., Misdorp, R., Niesing, H., Salman, A., Smallengange, M. (Eds.), 2004. Living with Coastal Erosion in Europe: Sediment and Space for Sustainability; Results from the Eurosion Study. Office for the Official Publications of the European Communities, Luxembourg. http://www. eurosion.org/project/eurosion_en.pdf.

EEA, 2006. Policy Research Based on EEA, 2006. The Changing Faces of Europe's Coastal Areas (For Sea Level Rise and $10 \mathrm{Km}$ Coastal Zone below 5 Meters Elevation). EEA Report No 6/2006.

EUROSTAT, 2016. Maritime economy statistics - coastal regions and sectoral perspective (for GDP and population in $50 \mathrm{~km}$ zone). http://ec.europa.eu/ eurostat/statistics-explained/index.php/Maritime_economy_statistics_coastal_regions_and_sectoral_perspective.

Farrugia, M., 2008. Coastal erosion along northern Malta: geomorphologica processes and risks. Geogr. Fis. Dinam. Quat. 31, 149-160.

Galdies, C., 2015. Potential future climatic conditions on tourists: a case study focusing on Malta and Venice. Xjenza Online 3, 6-25.

Galdies, C., Said, A., Camilleri, L., Caruana, M., 2016. Climate change trends in Malta and related beliefs, concerns and attitudes toward adaptation among Gozitan farmers. Eur. J. Agron. 74, 18-28.

Galea, P., D'Amico, S., Farrugia, D., 2014. Dynamic characteristics of an active coastal spreading area using ambient noise measurements (Anchor Bay, Malta). Geophys. J. Int. 199, 1166-1175. http://dx.doi.org/10.1093/gii/ggu318.

Gauci, M.J., Deidun, A., Schembri, P.J., 2005. Faunistic diversity of Maltese pocket sandy and shingle beaches: are these of conservation value? Oceanologia 47 (2), 219-241.

GHK, 2006. Strategic Evaluation on Environment and Risk Prevention under Structural and Cohesion Funds for the Period 2007-2013. Synthesis Report to the European Commission (DG REGIO), GHK in association with Ecolas, Institute for European Environmental Policy \& Cambridge Econometrics.

Hardy, J.T., 2003. Climate Change: Causes, Effects, and Solutions. John Wiley \& Sons, Sussex, England.

IPCC, 2007. In: Parry, M.L., Canziani, O.F., Palutikof, J.P., van der Linden, P.J., Hanson, C.E. (Eds.), Climate Change 2007: Impacts, Adaptation and Vulnerability: Contribution of Working Group II to the Fourth Assessment Report of the Intergovernmental Panel on Climate Change. Cambridge University Press, Cambridge, UK, p. 976.

IPCC, 2014. Climate Change 2014: Impacts, Adaptation, and Vulnerability. ( No. 1) IPCC. Cambridge University Press, Cambridge, United Kingdom and New York, USA, pp. 1-32. Retrieved from http://ipccwg2.gov/AR5/images/uploads/ WG2AR5 SPM FINAL.pdf.

Kay, R.C., Eriksen, N.J., Foster, G.A., Gillgren, D.J., Healy, T.R., Sheffield, A.T., Warrick, R.A., 1994. Assessment of Coastal Hazards and Their Management for Selected Parts of the Coastal Zone Administered by the Tauranga District Council. A Report to the Tauranga District Council and Environment Bay of Plenty.

Lazarow, N., Tomlinson, R., Pointeau, R., Strauss, D., Noriega, R., Kirkpatrick, S., Stuart, G., Hunt, S., 2010. Gold Coast Shoreline Management Plan. Research Report 90. Griffith Centre for Coastal Management.

Magri, O., 2006. A geological and geomorphological review of the Maltese islands with special reference to the coastal zone. Territoris 6, 7-26.

Magri, O., Mantovani, M., Pasuto, A., Soldati, M., 2007. Monitoring the state of activity of lateral spreading phenomena along the north-west coast of Malta using the GPS technique. Analele Univ. Din. Oradea 17, 5-10.

Magri, O., Mantovani, M., Pasuto, A., Soldati, M., 2008. Geomorphological investigation and monitoring of lateral spreading along the north-west coast of Malta. Geogr. Fis. Din. Quaternaria 31 (2), 171-180.

Mangor, K., 2004. Shoreline Management Guidelines. DHI Water and Environment, p. 294.

Masselink, G., Hughes, M.G., Knight, J., 2011. Introduction to Coastal Processes and Geomorphology, second ed. Routledge, Abingdon, U.K., p. 416

McInnes, R., 2009. Non-technical Guide to Coastal Risk Management, second ed. SCOPAC, UK.

MEPA, 2014. Terrestrial Habitats. Retrieved March 27, 2015, from. http://www. mepa.org.mt/biodiversity-habitats-terrestrial.

MEPA, 2015. Strategic Environmental Assessment Environment Report. The Malta Environment and Planning Authority (MEPA), July, 2015, p. 122.

Micallef, A., 2003. Monitoring beach stability on the mediterranean island of Malta. In: Ozhan, E. (Ed.), Proceedings of the Sixth International Conference on the Mediterranean Coastal Environments, MedCoast'03, Ravenna, Italy. MedCoast Secreteriat, Middle east Technical University, Ankara, Turkey, pp. 1357-1368.

Micallef, A., Williams, A., 2009. Shore platform denudation measurements along the Maltese coastline. J. Coast. Res. SI (56), 737-741.

Mimura, N., Nurse, L., McLean, R.F., Agard, J., Briguglio, L., Lefale, P., Payet, R., Sem, G., 2007. In: Parry, M.L., Canziani, O.F., Palutikof, J.P., van der Linden, P.J., Hanson, C.E. (Eds.), Small Islands. Climate Change 2007: Impacts, Adaptation and Vulnerability. Contribution of Working Group II to the Fourth Assessment Report of the Intergovernmental Panel on Climate Change. Cambridge University Press, Cambridge, UK, pp. 687-716.

MMA, 2003. Malta Significant Wave Height Study Main Report. Malta Maritime Authority, Malta, p. 39. December 2003.

MRA, 2012. Geological Map of Malta (Sheet 1). Retrieved January 11, 2015, from: http://mra.org.mt/wp-content/uploads/2012/09/Malta-Sheet-1.jpg.

MRRA, 2009. National Strategy for Policy and Abatement Measures Relating to the Reduction of Greenhouse Gas Emissions. Ministry for Resources and Rural Affairs, Government of Malta September 2009, p. 81.

MRRA, 2012. National Climate Change Adaptation Strategy. Ministry for Resources and Rural Affairs, Government of Malta, p. 64.

National Communication of Malta to the UNFCCC, 2014. The Third, Fourth, Fifth and Sixth National Communication of Malta under the United Nations Framework Convention on Climate Change. The Malta Resources Authority on behalf of the Ministry for Sustainable Development, Environment and Climate Change, p. 195.

Nicholls, R.J., Wong, P.P., Burkett, V., Codignotto, J., Hay, J., McLean, R., Arblaster, J., 2007. Coastal Systems and Low-lying Areas. Cambridge University Press, Cambridge, UK, pp. 315-356.

NSO, 2015. Census of Population and Housing, 2011-Preliminary Report. s.L. : National Statistics Office - Malta, 2012

NTM, 2015. Terrestrial Habitats. Retrieved March 27, 2015, from: http://www. 
naturetrustmalta.org/environmental-education/biodiversity/habitats/ terrestrian/.

Oil Exploration Directorate, 1993. The Geological Map of the Maltese Islands: 1:25, 000; 1 Map in 2 Parts on 2 Sheets. Office of the Prime Minister, Valletta, Malta.

Panzera, F., D'Amico, S., Lotteri, A., Galea, P., Lombardo, G., 2012. Seismic site response of unstable steep slope using noise measurements: the case study of Xemxija bay area, Malta. Nat. Hazard Earth Sci. Syst. 12, 3421-3431. http:// dx.doi.org/10.5194/nhess-12-3421-2012.

Pedley, H.M., House, M.R., Waugh, B., 1976. The geology of Malta and Gozo. Proc Geologists' Assocoation 87 (3), 325-341.

Planning Authority, 2002. Coastal Strategy Topic Paper, Final Draft. Planning Authority, Malta, pp. 42-84.

Policy Research Corporation, 2009. The Economics of Climate Change Adaptation in EU Coastal Areas - Malta. Final Report. Policy Research Corporation (in association with MRAG), Belgium, p. 163. Retrieved April 29, 2015, from: http://ec. europa.eu/maritimeaffairs/documentation/studies/documents/malta_climate change en.pdf.

Prahalad, V., Sharples, C., Kirkpatrick, J., Mount, R., 2015. Is wind-wave fetch exposure related to soft shoreline change in swell-sheltered situations with low terrestrial sediment input? J. Coast Conserv. 2015 (19), 23-33.

Tous, M., Romero, R., 2013. Meteorological environments associated with medicane development". International Journal of Climatology. R. Meteorol. Soc. 33 (1) $1-14$.

Tous, M., Romero, R., Ramis, C., 2013. Surface heat fluxes influence on medicane trajectories and intensification. Atmos. Res. 123, 400-411.

UNEP, 2012. UNEP Riso Releases Coastal Hazard Assessment Tool. Retrieved February 20, 2015, from: http://climate-l.iisd.org/news/unep-riso-releasescoastal-hazard-assessment-tool/.

UNFCCC, 2005. Climate Change, Small Island Developing States. Unpublished manuscript. Retrieved February 6, 2015, from: http://unfccc.int/resource/docs/ publications/cc_sids.pdf.

USGCRP (2014). Melillo, Jerry M., Terese (T.C.) Richmond, and Gary W. Yohe, Eds., 2014: Climate Change Impacts in the United States: The Third National Climate Assessment. U.S. Global Change Research Program. Pp. 841.

Walker-Leigh, V., 2006. In: Climate Change and Malta, Future Climate Change Policy: Looking beyond 2012, International Workshop 11-12 October 2006 Ljubljana.

Walsh, K., Giorgi, F. and E. Coppola (2014). "Mediterranean warm-core cyclones in a warmer world". Climate Dynamics. Springer Science+Business Media. 42 (3-4): 1053-1066. Bibcode:2014CIDy...42.1053W. doi:10.1007/s00382-013-1723-y.

Williams, A.T., Micallef, A., 2009. Beach Management: Principles and Practice. EARTHSCAN Publishers, London, U.K., p. 445 